\title{
Municipal sludge as source of nitrogen and phosphorus in perennial pasture Eragrostis curvula production: Agronomic benefits and environmental impacts
}

\author{
Eyob H Tesfamariam ${ }^{1 *}$, John G Annandale ${ }^{1}$, Joachim M Steyn ${ }^{1}$, Richard J Stirzaker ${ }^{2}$ and Ikenna Mbakwe ${ }^{1}$ \\ 'Department of Plant Production and Soil Science, University of Pretoria, Private Bag X20, 0002, Pretoria, South Africa \\ ${ }^{2}$ CSIRO Land and Water, PO Box 1666, ACT 2601, Australia and CRC for Irrigation Futures, PO Box 56, Darling Heights, Queensland, Australia 4350
}

\begin{abstract}
Land application of sludge has been shown to improve soil properties and aid crop growth, but the possibility of constituent nutrients such as nitrogen and phosphorus reaching environmentally toxic levels has caused governing authorities to set limits to how much sludge can be applied to agronomic land. The high nitrogen utilisation potential of pasture grasses suggests that more sludge can be used in this cropping system without the risk of excess nitrates. This study investigates the effect of exceeding the South African sludge application limit on hay yield, soil nitrates and phosphorus. Field plots were arranged in a complete block design comprising 4 replications of 4 treatments planted to Eragrostis curvula. The treatments consisted of $0,4,8$ and $16 \mathrm{Mg}$ ha ${ }^{-1}$ anaerobically digested sludge. Soil samples were collected before treatment application and at the end of each growing season for $\mathrm{N}, \mathrm{P}, \mathrm{NO}_{3}{ }^{-}, \mathrm{NH}_{4}^{+}$, and Bray-1P analyses. Plant samples were collected at flowering stage for hay yield and $\mathrm{N}$ and $\mathrm{P}$ uptake determination. Statistical analyses were conducted using analysis of variance (ANOVA) and general linear model (GLM) procedures of Windows SAS 9.0 to evaluate the effect of sludge application rates on hay yield. Results over 4 growing seasons indicate that exceeding the recommended limit increased hay yield by $4 \%$ in a

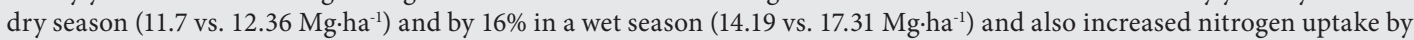
$15 \%$. Sludge applied at double the recommended limit did not cause the accumulation of nitrate and ammonium in the soil, however, both total and Bray-1P were doubled. The study shows that the potential long-term environmental risk of doubling the sludge application rate norm would be from labile $\mathrm{P}$ accumulation in the soil profile despite a sludge P:Fe molar ratio of less than unity.
\end{abstract}

Keywords: sludge, Eragrostis curvula, nitrogen, phosphorus, leaching

\section{INTRODUCTION}

Use of sewage sludge on agricultural land has been practised for a long time around the world, and has been shown to have several benefits. Sludge acts as a source of essential crop nutrients (Smith and Tibbett, 2004; Ferreiro-Domínguez et al., 2011), stimulates microbial activity (Boyle and Paul, 1989; Lakhdar et al., 2010), immobilises toxic elements in soil (Neunhäuserer et al., 2001), improves soil structure, and minimises soil erosion and runoff (Ojeda et al., 2008).

However, nutrients applied above a crop's nutrient requirement can be detrimental to plant growth and may ultimately pollute water bodies (Neal et al., 2002). Excess nitrates from sludge may be leached down and contaminate groundwater or be washed out into water bodies and exacerbate algal blooms. Excess phosphorus washed away from the soil may also enhance the rate of eutrophication in nearby water bodies (Xie et al., 2011). In addition, waste products from cities and industrial areas contain pathogens, toxic elements and organic contaminants which can pose a serious health hazard especially when they enter the food chain. For these reasons, many countries have developed sewage sludge guidelines to optimise agricultural benefits without compromising the environment.

To whom all correspondence should be addressed.

III +27 12420 4724; fax: +27 12420 4120;

e-mail: eyob.tesfamariam@up.ac.za

Received 2 October 2012; accepted in revised form 11 July 2013.
In South Africa, where beneficial agricultural use of sludge accounts for only $28 \%$ of the total sludge produced from South African wastewater treatment plants, the Water Research Commission initially pegged sludge application on land at not more than $8 \mathrm{Mg}$ per hectare per year. This is despite the enormous pressure on South African wastewater treatment plants to dispose of or utilise their sludge in an environmentally sustainable way. This limit has recently been increased to $10 \mathrm{Mg}$ per hectare per year (Snyman and Herselman, 2006). Nevertheless, the problem of sludge disposal still persists.

Generally, sludge of acceptable quality for agricultural use is applied according to crop nitrogen requirements (Milne and Graveland, 1972; Dotson, 1973), but some studies have shown that this approach may lead to a build-up of phosphorus in the soil profile (Pierzynski, 1994; Maguire et al., 2000, Tesfamariam et al., 2009). While these sludge application limits may be appropriate for most agronomic crops, can they be exceeded for perennial dryland pasture without compromising the environment? Perennial grasses have the potential to reduce nitrate leaching compared to annual crops due to their established root system. They are considered a good choice for repeated sludge applications because of their efficient nitrogen utilisation under intensive management practices and because a number of harvests can be made in a year (Bary et al., 2001). If sludge application rate can be increased for dryland pasture without compromising the environment, this management option may prove a better disposal method and help reduce the huge amounts of sludge that are usually left unutilised. 
This study investigates the effect, on pasture yield and soil nitrate and phosphorus levels, of applying sludge at a rate higher than the recommended limits. It is hypothesised that municipal sludge loading above the recommended limit would improve weeping lovegrass hay yield without causing excessive nitrate leaching. It is also hypothesised that surface application of $\mathrm{FeCl}_{3}$ treated municipal sludge ( $<1 \mathrm{P}$ :Fe molar ratio) according to weeping lovegrass $\mathrm{N}$ demand would result in the accumulation of total and Bray-1P in the soil profile.

\section{MATERIALS AND METHODS}

\section{Field site description}

Field experiments were conducted at the East Rand Water Care Works (ERWAT), Johannesburg, Gauteng, South Africa. The study site is situated at an elevation of $1577 \mathrm{~m}$ above sea level, latitude $26^{\circ} 01^{\prime} 01^{\prime \prime} \mathrm{S}$ and longitude of $28^{\circ} 16^{\prime} 55^{\prime \prime} \mathrm{E}$. The total annual rainfall of the area ranged between $405 \mathrm{~mm}$ in 2006/07 and $710 \mathrm{~mm}$ in 2007/08, mainly during the months of October to March. The soil of the experimental site is a clay loam, Hutton soil form (Soil Classification Working Group, 1991) having an average clay content of $38 \%$, and $\mathrm{pH}\left(\mathrm{H}_{2} \mathrm{O}\right)$ of 5.73 . At the onset of the study, the mean cation exchange capacity of the soil (ammonium acetate extract) was $11 \mathrm{cmol} \cdot \mathrm{kg}^{-1}$ and the electrical conductivity ranged from $8 \mathrm{mS} \cdot \mathrm{m}^{-1}$ at $1.2 \mathrm{~m}$ depth to $36 \mathrm{mS} \cdot \mathrm{m}^{-1}$ in the top $0.3 \mathrm{~m}$ soil layer.

\section{Sludge characteristics}

The sludge used in this study was anaerobically digested and paddy-dried, collected from Vlakplaas Wastewater Treatment Plant. According to the current South African sludge guideline (Snyman and Herselman, 2006), this sludge is classified as pollutant Class 'a' due to its low heavy metal content. Based on low levels of faecal coliform and helminth ova, the sludge is classified as microbiological Class ' $A$ '. With respect to sludge stability, the sludge is classified as Class ' 1 ' due to its low odour and low vector attraction characteristics. The current South African guideline for the utilisation and disposal of wastewater sludge (Snyman and Herselman, 2006) allows such quality sludges to be utilised in agriculture without restriction, as long as the $\mathrm{N}$ applied does not exceed crop demand, with the upper limit set at $10 \mathrm{Mg} \mathrm{ha}^{-1} \cdot \mathrm{yr}^{-1}$. Selected properties of this Ala sludge are presented in Table 1.

\section{Field trial plots and treatments}

Plots of $25 \mathrm{~m}^{2}$ were arranged in a randomised complete block design comprising 4 replications of 4 treatments. The trial was laid out to accommodate widely different levels of bio-solid application.

\begin{tabular}{|c|c|c|c|c|c|}
\hline \multicolumn{6}{|c|}{$\begin{array}{l}\text { TABLE } 1 \\
\text { Some properties of sludge used during the 2004/05 - } \\
\text { 2007/08 growing seasons }\end{array}$} \\
\hline \multirow{2}{*}{$\begin{array}{l}\text { Parameter } \\
\text { measured }\end{array}$} & \multirow[t]{2}{*}{ Unit } & \multicolumn{4}{|c|}{ Year } \\
\hline & & $2004 / 05$ & $2005 / 06$ & $2006 / 07$ & $2007 / 08$ \\
\hline $\mathrm{N}$ & $\%$ & 3.032 & 1.884 & 2.219 & 3.094 \\
\hline $\mathrm{NH}_{4-} \mathrm{N}$ & $\mathrm{mg} \cdot \mathrm{kg}^{-1}$ & 2018 & 4362 & 4064 & 7660 \\
\hline $\mathrm{NO}_{3-} \mathrm{N}$ & $\mathrm{mg} \cdot \mathrm{kg}^{-1}$ & 183 & 6 & 40 & 11 \\
\hline $\mathrm{P}$ & $\%$ & 1.962 & 1.844 & 2.76 & 2.24 \\
\hline P - Brayl & $\mathrm{mg} \cdot \mathrm{kg}^{-1}$ & 166 & 154 & 40 & 66 \\
\hline Total C & $\%$ & 23 & 20 & 21 & 20 \\
\hline Water content & $\%$ & 46 & 30 & 28 & 38 \\
\hline $\mathrm{EC}_{e}$ & $\mathrm{mS} \cdot \mathrm{m}^{-1}$ & 1814 & 1212 & 1412 & 3110 \\
\hline $\mathrm{K}$ & $\mathrm{mg} \cdot \mathrm{kg}^{-1}$ & 3804 & 710 & 689 & 1356 \\
\hline $\mathrm{Ca}$ & $\mathrm{mg} \cdot \mathrm{kg}^{-1}$ & 25116 & 13062 & 17450 & 10042 \\
\hline $\mathrm{Mg}$ & $\mathrm{mg} \cdot \mathrm{kg}^{-1}$ & 5358 & 591 & 829 & 1145 \\
\hline $\mathrm{pH}\left(\mathrm{H}_{2} \mathrm{O}\right)$ & & 6.01 & 6.2 & 6.02 & 6.08 \\
\hline $\mathrm{Cd}$ & $\mathrm{mg} \cdot \mathrm{kg}^{-1}$ & 1.63 & 0.07 & 0.15 & 18.91 \\
\hline $\mathrm{Hg}$ & $\mathrm{mg} \cdot \mathrm{kg}^{-1}$ & 1.70 & 0.02 & 0.03 & 1.81 \\
\hline $\mathrm{Cr}$ & $\mathrm{mg} \cdot \mathrm{kg}^{-1}$ & 51.93 & 1.50 & 2.92 & 503.8 \\
\hline As & $\mathrm{mg} \cdot \mathrm{kg}^{-1}$ & 7.08 & 0.18 & 0.23 & 17.94 \\
\hline $\mathrm{Pb}$ & $\mathrm{mg} \cdot \mathrm{kg}^{-1}$ & 54.46 & 9.41 & 1.37 & 102.0 \\
\hline $\mathrm{Zn}$ & $\mathrm{mg} \cdot \mathrm{kg}^{-1}$ & 459.9 & 4.33 & 20.85 & 2325 \\
\hline $\mathrm{Ni}$ & $\mathrm{mg} \cdot \mathrm{kg}^{-1}$ & 23.81 & 1.37 & 0.97 & 144.5 \\
\hline $\mathrm{Cu}$ & $\mathrm{mg} \cdot \mathrm{kg}^{-1}$ & 97.2 & 3.21 & 4.59 & 526.8 \\
\hline
\end{tabular}

Treatments consisted of 3 sludge rates $\left(4,8\right.$, and $\left.16 \mathrm{Mg} \mathrm{ha}^{-1} \cdot \mathrm{yr}^{-1}\right)$ and an unamended zero control. The annual sludge application rate was split into two so that half was applied at the beginning of the season and the remaining half following the first cut.

At the onset of the study, during the 2004/05 growing season, sludge was broadcast over the soil surface and immediately incorporated into the top $10 \mathrm{~cm}$ soil layer with a manually-operated, diesel-powered rotovator (Agria). After sludge incorporation, the soil was levelled using rakes. A mixture of weeping lovegrass (Eragrostis curvula) $\left(10 \mathrm{~kg} \cdot \mathrm{ha}^{-1}\right)$ and teff (Eragrostis teff) $\left(6 \mathrm{~kg} \cdot \mathrm{ha}^{-1}\right)$ was planted on 15 November 2004 and a hand-drawn roller was used to ensure good seed-soil contact for better germination. During the rest of the study period, however, sludge was broadcast over the soil surface of the already established weeping lovegrass plots and left on the soil surface without incorporation. Sludge application and haycutting dates are presented in Table 2.

\section{Weather data}

Weather data were collected from an automatic weather station located about $100 \mathrm{~m}$ from the experimental site. The automatic

\section{TABLE 2}

Sludge application and hay cutting dates for Weeping lovegrass during the 2004/05 to 2007/08 growing seasons at ERWAT, Ekurhuleni district, South Africa

\begin{tabular}{|l|c|c|c|c|}
\hline \multirow{2}{*}{$\begin{array}{l}\text { Growing } \\
\text { season }\end{array}$} & \multicolumn{2}{|c|}{ Sludge application date } & \multicolumn{2}{c|}{ Hay cutting date } \\
\cline { 2 - 5 } & First & Second & First & Second \\
\hline $2004 / 05$ & $14 / 11 / 2004$ & $20 / 02 / 2005$ & $17 / 02 / 2005$ & $22 / 05 / 2005$ \\
\hline $2005 / 06$ & $01 / 11 / 2005$ & $20 / 02 / 2006$ & $31 / 01 / 2006$ & $11 / 05 / 2006$ \\
\hline $2006 / 07$ & $20 / 10 / 2006$ & $10 / 01 / 2007$ & $09 / 01 / 2007$ & $16 / 04 / 2007$ \\
\hline $2007 / 08$ & $26 / 09 / 2007$ & $14 / 01 / 2008$ & $11 / 01 / 2008$ & $16 / 04 / 2008$ \\
\hline
\end{tabular}




\begin{tabular}{|c|c|c|c|c|c|c|c|c|c|c|c|c|c|c|c|c|c|c|c|c|c|}
\hline & $\begin{array}{l}\text { Two-w } \\
\text { precip }\end{array}$ & ekly r & nea & $m$ & $\begin{array}{l}\text { num an } \\
\text { e 2004/ }\end{array}$ & $\begin{array}{l}\text { nd mi } \\
4 / 05 \text { to }\end{array}$ & $\begin{array}{l}\text { nimur } \\
2008\end{array}$ & $\begin{array}{l}n \text { tem } \\
3 / 09 \mathrm{~g}\end{array}$ & $\begin{array}{l}\text { perat } \\
\text { rowin }\end{array}$ & $\begin{array}{l}\text { TABLE } \\
\text { ure, me } \\
\text { g seasc }\end{array}$ & $\begin{array}{l}3 \\
\text { ean a } \\
\text { ons, } E\end{array}$ & $\begin{array}{l}\text { verag } \\
\text { RWAT }\end{array}$ & $\begin{array}{l}\text { e tem } \\
\text { r, Ekur }\end{array}$ & $\begin{array}{l}\text { perat } \\
\text { hulen }\end{array}$ & $\begin{array}{l}\text { ure, a } \\
\text { i dist }\end{array}$ & $\begin{array}{l}\text { nd two } \\
\text { ict Pre }\end{array}$ & $\begin{array}{l}\text { o-wee } \\
\text { etoria, }\end{array}$ & $\begin{array}{l}\text { akly cut } \\
\text {, Soutt }\end{array}$ & $\begin{array}{l}\text { mulat } \\
\text { h Afric }\end{array}$ & & \\
\hline Period & & & & 04 & & & 20 & 05 & & & 20 & 06 & & & 20 & 07 & & & 20 & 08 & \\
\hline & & Temp & eratu & $\left({ }^{\circ} \mathrm{C}\right)$ & Rain & Temp & eratur & e $\left({ }^{\circ} \mathrm{C}\right)$ & Rain & Tempe & eratur & e $\left({ }^{\circ} \mathrm{C}\right)$ & Rain & Temp & eratur & e $\left({ }^{\circ} \mathrm{C}\right)$ & Rain & Temp & eratur & e $\left({ }^{\circ} \mathrm{C}\right)$ & Rain \\
\hline Month & Weeks & Max. & Min. & Ave. & $(\mathrm{mm}) \Lambda$ & Max. & Min. & Ave. & & Max. & Min. & Ave. & & Max. & Min. & Ave. & & Max. & Min. & Ave. & \\
\hline Jan. & $1-2$ & & & & & 29 & 16 & 23 & 111 & 26 & 17 & 21 & 51 & 29 & 13 & 21 & 47 & 24 & 15 & 20 & 59 \\
\hline & $3-4$ & & & & & 26 & 16 & 21 & 56 & 26 & 15 & 21 & 57 & 29 & 14 & 21 & 24 & 23 & 14 & 18 & 148 \\
\hline Feb. & $1-2$ & & & & & 29 & 16 & 22 & 17 & 26 & 15 & 20 & 103 & 30 & 13 & 21 & 30 & 25 & 14 & 19 & 56 \\
\hline & $3-4$ & & & & & 27 & 15 & 21 & 79 & 27 & 15 & 21 & 70 & 32 & 14 & 23 & 0 & 27 & 15 & 21 & 5 \\
\hline Mar. & $1-2$ & & & & & 27 & 12 & 20 & 27 & 24 & 12 & 18 & 13 & 30 & 13 & 22 & 6 & 24 & 14 & 19 & 117 \\
\hline & $3-4$ & & & & & 25 & 12 & 18 & 44 & 23 & 12 & 18 & 38 & 27 & 11 & 19 & 7 & 22 & 11 & 16 & 42 \\
\hline Apr. & $1-2$ & & & & & 23 & 11 & 17 & 45 & 24 & 9 & 17 & 10 & 26 & 10 & 18 & 0 & 24 & 11 & 18 & 17 \\
\hline & $3-4$ & & & & & 22 & 8 & 15 & 18 & 21 & 8 & 14 & 9 & 21 & 8 & 15 & 19 & 24 & 10 & 17 & 0 \\
\hline May & $1-2$ & & & & & 23 & 5 & 14 & 1 & 21 & 5 & 13 & 0 & 21 & 5 & 13 & 0 & 22 & 10 & 16 & 33 \\
\hline & $3-4$ & & & & & 2 & 4 & 13 & 0 & 19 & 2 & 10 & 3 & 19 & 0 & 10 & 0 & 19 & 8 & 13 & 10 \\
\hline June & $1-2$ & & & & & 22 & 3 & 12 & 0 & 22 & 3 & 12 & 0 & 18 & 3 & 10 & 29 & 17 & 6 & 12 & 14 \\
\hline & $3-4$ & & & & & 20 & 2 & 11 & 0 & 18 & 1 & 9 & 0 & 18 & 1 & 9 & 0 & 18 & 6 & 12 & 3 \\
\hline July & $1-2$ & & & & & 19 & 1 & 10 & 0 & 20 & 2 & 11 & 0 & 17 & 0 & 8 & 0 & 16 & 5 & 10 & 0 \\
\hline & $3-4$ & & & & & 22 & 2 & 12 & 0 & 22 & 4 & 13 & 0 & 20 & 1 & 11 & 0 & 18 & 6 & 12 & 0 \\
\hline Aug. & $1-2$ & & & & & 22 & 4 & 13 & 0 & 20 & 3 & 11 & 10 & 21 & 2 & 11 & 0 & 20 & 7 & 14 & 0 \\
\hline & $3-4$ & & & & & 24 & 7 & 15 & 0 & 21 & 6 & 14 & 30 & 22 & 4 & 13 & 0 & 22 & 9 & 15 & 0 \\
\hline Sep. & $1-2$ & & & & & 26 & 8 & 17 & 0 & 24 & 6 & 15 & 0 & 27 & 13 & 20 & 0 & 25 & 9 & 17 & 0 \\
\hline & $3-4$ & & & & & 29 & 10 & 19 & 0 & 26 & 8 & 16 & 0 & 25 & 11 & 18 & 17 & 23 & 9 & 16 & 0 \\
\hline Oct. & $1-2$ & & & & & 28 & 10 & 19 & 0 & 28 & 12 & 20 & 0 & 21 & 10 & 16 & 85 & 26 & 12 & 19 & 0 \\
\hline & $3-4$ & & & & & 29 & 12 & 20 & 12 & 31 & 14 & 22 & 13 & 22 & 11 & 16 & 34 & 27 & 14 & 20 & 62 \\
\hline Nov. & $1-2$ & 30 & 15 & 22 & 12 & 28 & 13 & 20 & 55 & 28 & 13 & 21 & 42 & 25 & 13 & 19 & 4 & 26 & 14 & 20 & 52 \\
\hline & $3-4$ & 30 & 15 & 23 & 29 & 28 & 13 & 21 & 54 & 26 & 14 & 20 & 75 & 26 & 14 & 20 & 45 & 25 & 15 & 20 & 45 \\
\hline Dec. & $1-2$ & 28 & 16 & 22 & 72 & 26 & 14 & 20 & 35 & 30 & 15 & 22 & 13 & 23 & 13 & 18 & 68 & 27 & 15 & 21 & 59 \\
\hline & $3-4$ & 28 & 15 & 22 & 64 & 28 & 13 & 20 & 68 & 29 & 17 & 23 & 121 & 25 & 14 & 19 & 12 & 27 & 15 & 21 & 67 \\
\hline
\end{tabular}

weather station consisted of an LI 200X pyranometer (LiCor, Lincoln, Nebraska, USA) for measuring solar radiation, an electronic relative humidity and temperature sensor (Thermistor Humitter 50Y) installed in a gill screen (R.M. Young, Minnesota, USA), an electronic cup anemometer to measure wind speed (R.M. Young, Minnesota, USA), an electronic rain gauge Model TR-525M-R2 (Texas Electronic Inc., Dallas, Texas, USA), and a CR10X data-logger (Campbell Scientific Inc., Utah, USA). Two-weekly mean maximum, minimum and average temperature as well as two-weekly cumulative precipitation are presented in Table 3.

\section{Soil solution sampling and analyses}

Nitrate leaching was monitored by wetting front detectors (WFDs) installed both at 0.3 and $0.6 \mathrm{~m}$ depths located in the middle of a plot. The detectors were installed in the control, 8 and $16 \mathrm{Mg} \cdot \mathrm{ha}^{-1} \cdot \mathrm{yr}^{-1}$ plots. Soil solution samples collected from the wetting front detectors were analysed for nitrate concentration using a C99 Multiparameter Bench Photometer (Hanna Instruments, Italy).

\section{Plant sampling}

Above-ground samples for hay yield determination were collected $0.05 \mathrm{~m}$ above the soil surface at flowering, from a $1 \mathrm{~m}^{2}$ area. These were then dried in a forced-air oven at $60^{\circ} \mathrm{C}$ for
$48 \mathrm{~h}$ to determine above-ground biomass. Above-ground biomass was calculated as the sum of leaf and stem. In addition, a hand grab of grass samples was collected at harvest from each plot for grass $\mathrm{N}$ and $\mathrm{P}$ uptake determination. A $0.5 \mathrm{~m}$ border was left around all sides of each plot during sampling to eliminate border effects.

\section{Soil sampling}

At the beginning of the study, before treatment application, and at the end of each growing season, soil samples were collected from each plot, using an auger, from the following layers: $0-0.1 \mathrm{~m}, 0.1-0.3 \mathrm{~m}, 0.3-0.5 \mathrm{~m}$, and $0.5-0.8 \mathrm{~m}$. Replicate samples from each layer in the same plot were combined and mixed to make a single homogeneous soil sample. All soil samples were dried and pulverised. The dried and ground soil samples were digested and analysed for $\mathrm{N}, \mathrm{P}, \mathrm{NO}_{3}, \mathrm{NH}_{4}^{+}$, and Bray-1P.

\section{Plant, sludge and soil chemical analyses}

Total P in sludge, soil, and plant samples were determined after wet acid digestion using an Inductively Coupled Plasma Optical Emission Spectrometer (ICP-OES) (SpectroFlame Modula; Spectro, Kleve, Germany). Plant extractable soil P was analysed using the Bray-1 extraction method, following standard procedures (Non-affiliated Soil Analysis Work Committee, 1990). Soil and plant samples were ground to pass through a 
$150 \mu \mathrm{m}$ screen and analysed for total C and $\mathrm{N}$ using a Carlo Erba NA1500 C/N analyser (Carlo ErbaStrumentazione, Milan, Italy). Soil samples were extracted in 1:5 $1 \mathrm{M} \mathrm{KCl}$ and tested for ammonium and nitrate with the Lachat Autoanalyzer (Lachat Quick Chem Systems, Milwaukee, WI, USA).

\section{Statistical analyses}

Statistical analyses were performed to evaluate the impact of various sludge application rates on hay yield. The statistical analyses were conducted using analysis of variance (ANOVA) and general linear model (GLM) procedures of Windows SAS version 9.0 (SAS Institute, 2002), to determine significant treatment effects on measured response variables. When treatment effects were found to be significant, Fisher's protected LSD at the 0.05 level was used to separate means.

\section{RESULTS AND DISCUSSION}

\section{Hay yield}

Hay yield increased with increase in sludge rate (Fig 1). A maximum of $17.3 \mathrm{Mg} \cdot \mathrm{ha}^{-1}$ was recorded during the $2007 / 08$ season

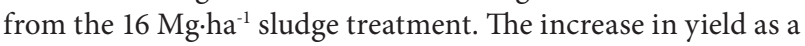
result of sludge addition is attributed to an increased supply of plant nutrients and to improvement of soil physical properties (Ferreiro-Domínguez et al., 2011).

In general, hay yield throughout the study period was much higher than the long-term average values of $6{\mathrm{Mg} \cdot \mathrm{ha}^{-1}}^{-1}$ reported by Dickinson et al. (2004) from Hutton soils receiving similar annual rainfall. This is most probably due to a better nutrient status of the soil from this study compared with the soils reported by Dickinson et al. (2004).

Generally, hay yield was highest in the 2007/08 season and, in addition to a cumulative improvement of soil chemical and physical properties, this higher yield observed during the 2007/08 season may be attributed to the higher rainfall received during the period (Table 3). Miles and Manson (2000) and Dickinson et al. (2004) have reported that weeping lovegrass response to $\mathrm{N}$ increases with increase in the availability of water. This may not be unconnected with the increase in the rate of nitrogen mineralisation which increases as soil moisture increases, up to an optimum (Agehara and Warncke, 2005).

\section{Soil total $\mathbf{N}$ mass balance}

Based on the mass balance calculation of $\mathrm{N}$ imported with sludge less $\mathrm{N}$ exported with hay, total $\mathrm{N}$ from sludge applied according to the initial $8 \mathrm{Mg} \cdot \mathrm{ha}^{-1}$ limit was close to being, but not quite sufficient to satisfy weeping lovegrass $\mathrm{N}$ demand (net negative mass balance) (Table 4, Column 4). Negative mass balances of all but the $16 \mathrm{Mg} \cdot \mathrm{ha}^{-1}$ treatment show that the crop utilised $\mathrm{N}$ from the soil reserve. Therefore, total $\mathrm{N}$ supply from sludge with $2.56 \%$ mean $\mathrm{N}$ applied according to the initial 8 $\mathrm{Mg} \cdot \mathrm{ha}^{-1}$ norm is not sufficient for optimal weeping lovegrass hay production under the prevailing climatic and soil conditions. Doubling of that upper limit sludge norm, however, resulted in a net positive mass balance. This indicates that the total $\mathrm{N}$ supply surpassed hay $\mathrm{N}$ uptake. The excess $\mathrm{N}$ from double the norm was accumulated mainly in the $0-0.1 \mathrm{~m}$ soil layer

(Fig. 2), because the sludge was surface applied.

Soil profile sampling to a depth of $0.8 \mathrm{~m}$ (Table 4 , Column 5) showed similar trends to the supply less uptake mass balance

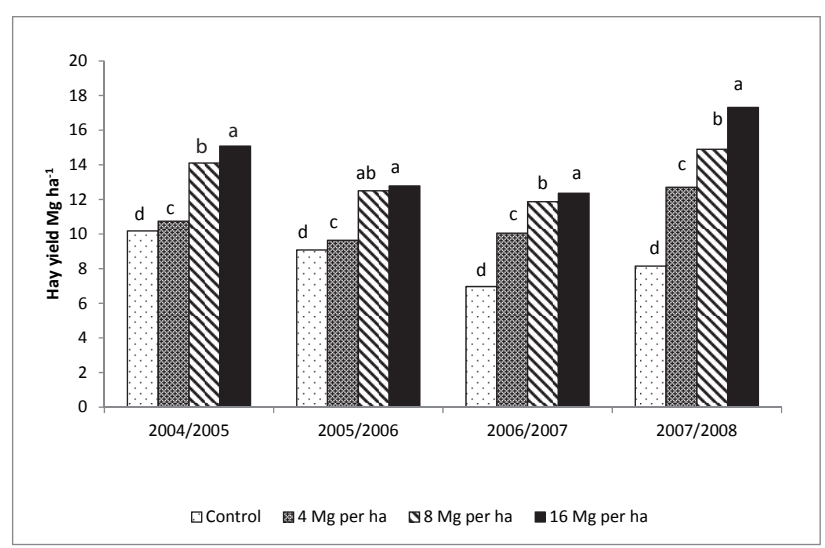

Figure 1

Annual hay yield of weeping lovegrass as affected by 3 sludge application rates, and an unamended control. Letters show significance within growing seasons.

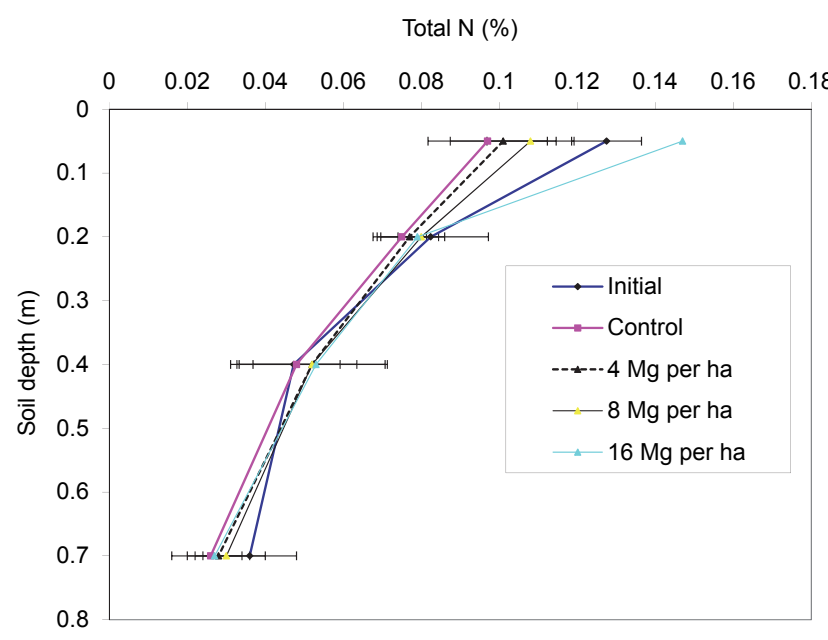

Figure 2

Soil profile total $N$ before treatment application (initial) and after 4 consecutive years of study with 3 sludge rates $(4,8$, and

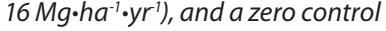

\begin{tabular}{|c|c|c|c|c|c|}
\hline \multicolumn{6}{|c|}{$\begin{array}{c}\text { TABLE } 4 \\
\text { Cumulative N supply (CUM-NS)), uptake (CUM-NU), and mass } \\
\text { balance of a weeping lovegrass treated with three sludge } \\
\text { application rates, and an unamended control }\end{array}$} \\
\hline \multirow[b]{2}{*}{ Treatment } & \multicolumn{5}{|c|}{\begin{tabular}{|l|} 
Four years cumulative mass balance \\
\end{tabular}} \\
\hline & $\begin{array}{l}\text { CUM-NS } \\
\left(\mathbf{k g} \cdot \mathbf{h a}^{-1}\right)\end{array}$ & $\begin{array}{l}\text { CUM-NU } \\
\left(\mathbf{k g} \cdot \mathrm{ha} \mathbf{a}^{-1}\right)\end{array}$ & $\begin{array}{c}\text { CUM-NS } \\
\text { less CUM- } \\
\text { NU } \\
\left(\mathbf{k g} \cdot \text { ha }^{-1}\right)\end{array}$ & $\begin{array}{l}\text { Change } \\
\text { in soil N } \\
\text { storage } \\
\left(\mathrm{kg}^{\mathrm{a}} \cdot \mathrm{ha}^{-1}\right)\end{array}$ & $\begin{array}{c}\text { Mass } \\
\text { balance } \\
\text { difference } \\
\left(\mathbf{k g} \cdot \text { ha }^{-1}\right)\end{array}$ \\
\hline Control & 0 & 511 & -511 & -600 & 89 \\
\hline $4 \mathrm{Mg} \cdot \mathrm{ha}^{-1} \cdot \mathrm{yr}^{-1}$ & 409 & 687 & -278 & -381 & 103 \\
\hline $8 \mathrm{Mg} \cdot \mathrm{ha}^{-1} \cdot \mathrm{yr}^{-1}$ & 818 & 856 & -38 & -203 & 165 \\
\hline $16 \mathrm{Mg} \cdot \mathrm{ha}^{-1} \cdot \mathrm{yr}^{-1}$ & 1637 & 988 & 649 & 330 & 319 \\
\hline
\end{tabular}

${ }^{a}$ Change in soil $N$ storage refers to final less initial soil profile $N$ content change to a depth of $80 \mathrm{~cm}$.

${ }^{b}$ Mass balance difference refers to the difference between (CUM-NS less CUM-NU) and change in soil $N$ storage.

(Table 4, Column 4). According to this profile analysis, the $16 \mathrm{Mg} \cdot \mathrm{ha}^{-1}$ sludge rate resulted in a net positive mass balance while sludge applied at the rate of $8 \mathrm{Mg} \cdot \mathrm{ha}^{-1}$ had a net negative 


\begin{tabular}{|c|c|c|c|}
\hline \multicolumn{4}{|c|}{$\begin{array}{c}\text { TABLE } 5 \\
\text { Residual nitrate mass in the top } 0.5 \mathrm{~m} \text { soil stratum of } \\
\text { weeping lovegrass plots treated with } 3 \text { sludge rates, and an } \\
\text { unamended control treatment }\end{array}$} \\
\hline \multirow[t]{2}{*}{ Treatment } & Initial & $\begin{array}{c}\text { After } 2^{\text {nd }} \text { hay } \\
\text { cut in 2005/06 }\end{array}$ & $\begin{array}{l}\text { After } 2^{\text {nd }} \text { hay } \\
\text { cut in } 2007 / 08\end{array}$ \\
\hline & \multicolumn{3}{|c|}{$\mathrm{kg} \cdot \mathrm{ha}^{-1}$} \\
\hline Control & 96 & 60 & 18 \\
\hline $4 \mathrm{Mg} \cdot \mathrm{ha}^{-1} \cdot \mathrm{yr}^{-1}$ & 96 & 62 & 18 \\
\hline $8 \mathrm{Mg} \cdot \mathrm{ha}^{-1} \cdot \mathrm{yr}^{-1}$ & 96 & 52 & 16 \\
\hline $16 \mathrm{Mg} \cdot \mathrm{ha}^{-1} \cdot \mathrm{yr}^{-1}$ & 96 & 51 & 58 \\
\hline
\end{tabular}

mass balance. Interestingly, however, there was a net positive difference between the two mass balances: supply less uptake (CUM_NS less CUM-NU) and change in storage between final and initial soil profile $\mathrm{N}$ contents (Change in soil $\mathrm{N}$ storage) (Table 4, Column 6). This difference increased with increase in sludge application rate (mass balance difference).

The most probable cause for the mass balance difference was ammonia volatilisation losses, which is not accounted for in the $\mathrm{N}$ import less export mass balance. This is because the sludge used in this study was anaerobically digested with about $20-25 \%$ of total $\mathrm{N}$ in ammonium form. In addition, the sludge was surface applied. Previous studies conducted by Adamsen and Sabey (1987) showed that $40.3 \%$ of the $\mathrm{NH}_{4}-\mathrm{N}$ from surface-applied sludge could be lost as $\mathrm{NH}_{3}$ gas during the first two weeks of its application. This was in contrast to $0.35 \%$ loss from an incorporated sludge reported in the same study. Martines et al. (2010) reported a $35 \%$ loss as ammonia, of the total $\mathrm{NH}_{4}-\mathrm{N}$ in a surface-applied sludge. Some other studies have also shown that up to $89 \%$ of the initial ammonium could be lost in the form of ammonia gas from a surface-applied anaerobicallydigested sludge (Henry et al., 1999). Other possible sources of the differences include sampling errors, $\mathrm{N}$ content variation within the sludge matrix, soil heterogeneity, and probably denitrification (which is not expected to dominate under dryland cropping), and leaching (which could have been insignificant due to the low rainfall).

\section{Residual nitrate and nitrate leaching}

Residual nitrate in the top $0.5 \mathrm{~m}$ soil layer of all treatments,

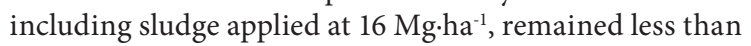
the initial amount throughout the study period (Table 5). The reduction in nitrate content of all treatments was evident in the $0-0.3 \mathrm{~m}$ soil stratum, while the content in the $0.3-0.8 \mathrm{~m}$ layer remained similar to initial values (Fig. 3). It was also evident that sludge applied at $16 \mathrm{Mg} \cdot \mathrm{ha}^{-1}$ had relatively lower residual nitrate than that of lower sludge rates in $2005 / 06$, but this was higher at the end of the 2007/08 growing season.

Although residual nitrate at the end of the study was rela-

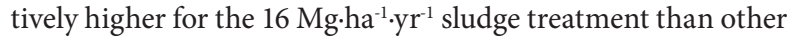
treatments, it was still low and was almost half of the initial mass. The main reason for monitoring residual nitrate after harvest was that nitrate leaching under dryland conditions usually takes place at the beginning of the rainy season, especially before active root nutrient uptake in the presence of high rainfall and residual soil nitrate. Nitrate is susceptible to diffusion and transport through mass flow with soil water, because there is little tendency for the mostly negatively-charged soil colloids to adsorb the negatively-charged nitrate (Cameron and Haynes, 1986).

In this specific study the mean annual rainfall was low (405 $\mathrm{mm}$ in 2007) to moderate (710 $\mathrm{mm}$ in 2008). The wetting

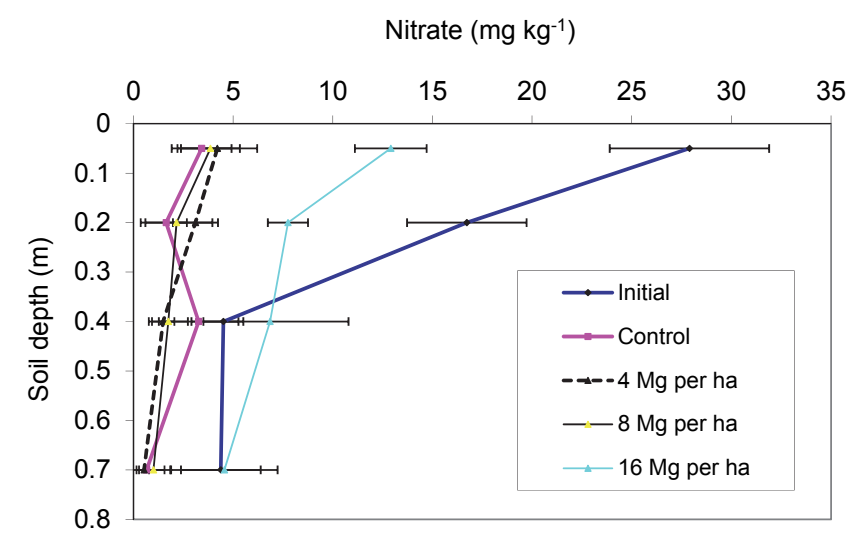

Figure 3

Residual nitrate before treatment application (initial) and after 4 consecutive years of sludge application at 3 rates

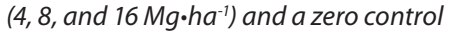

\begin{tabular}{|c|c|c|c|}
\hline \multicolumn{4}{|c|}{$\begin{array}{l}\text { TABLE } 6 \\
\text { Residual ammonium mass in the top } 0.5 \mathrm{~m} \text { soil stratum } \\
\text { after every second weeping lovegrass hay cut during } \\
\text { the } 2004 / 05 \text { to } 2007 / 08 \text { growing seasons }\end{array}$} \\
\hline Treatment & $\begin{array}{c}\text { Initial } \\
\left(\mathbf{k g} \cdot \mathrm{ha}^{-1}\right)\end{array}$ & $\begin{array}{l}\text { After } 2^{\text {nd }} \text { hay } \\
\text { cut in } 2005 / 06 \\
\left(\mathrm{~kg} \cdot \mathrm{ha}^{-1}\right)\end{array}$ & $\begin{array}{c}\text { After } 2^{\text {nd }} \text { hay } \\
\text { cut in 2007/08 } \\
\left(\mathrm{kg} \cdot \mathrm{ha}^{-1}\right)\end{array}$ \\
\hline Control & 65 & 16 & 20 \\
\hline $4 \mathrm{Mg} \cdot h \mathrm{ha}^{-} \cdot \mathrm{yr}^{-1}$ & 65 & 41 & 38 \\
\hline $8 \mathrm{Mg} \mathrm{ha}^{-1} \cdot \mathrm{yr}^{-1}$ & 65 & 31 & 46 \\
\hline $16 \mathrm{Mg} \cdot \mathrm{ha}^{-1} \cdot \mathrm{yr}^{-1}$ & 65 & 36 & 65 \\
\hline
\end{tabular}

front detectors buried at $0.3 \mathrm{~m}$ depth responded only 4 times during the 4 -year study period. The dates of response and the corresponding nitrate concentrations from the $16 \mathrm{Mg} \cdot \mathrm{ha}^{-1} \cdot \mathrm{yr}^{-1}$ sludge treatment were: $21 / 02 / 2005\left(10 \mathrm{mg} \cdot \ell^{-1} \mathrm{NO}_{3}\right), 01 / 03 / 2006$ (14 mg $\cdot \ell^{-1} \mathrm{NO}_{3}$ ), 22/01/2008 (8 mg. $\ell^{-1} \mathrm{NO}_{3}$ ), and 16/03/2008 $\left(11 \mathrm{mg} \cdot \ell^{-1} \mathrm{NO}_{3}\right.$ ). The control and $8 \mathrm{Mg} \cdot \mathrm{ha}^{-1} \cdot \mathrm{yr}^{-1}$ sludge treatments had similar or lower nitrate concentrations during the same time period. None of the WFDs buried at $0.6 \mathrm{~m}$, however, responded. Therefore, considering the low to moderate rainfall experienced during the study period, low residual nitrate, and low nitrate concentrations collected during very few events might indicate that nitrate leaching was minimal during the study period.

\section{Residual ammonium}

Residual ammonium in the top $0.5 \mathrm{~m}$ soil stratum remained equal or less than initial values for all treatments (Table 6). Residual ammonium, however, increased with increase in sludge application rate at the end of the 2007/08 growing season, but did not show any specific trend in 2005/06.

Despite the net positive total $\mathrm{N}$ mass balance of the 16 $\mathrm{Mg} \cdot \mathrm{ha}^{-1} \cdot \mathrm{yr}^{-1}$ sludge treatment (Table 4, Columns 4 and 5), residual ammonium and nitrate remained similar to or less than initial values. This indicates that a large fraction of the $\mathrm{N}$ in the soil is present in organic form. This might also indicate that the ammonium added from the sludge was either nitrified or taken up by the plants. The possibility for ammonium to leach below the active root zone $(0-0.6 \mathrm{~m})$ in this specific soil type under the prevailing rainfall and sludge rates is unlikely, considering that primarily, the predominantly negatively charged soil clay 


\begin{tabular}{|c|c|c|c|c|c|}
\hline \multicolumn{6}{|c|}{$\begin{array}{c}\text { TABLE 7 } \\
\text { Cumulative total P supply (CUM-PS), uptake (CUM-PU), and } \\
\text { mass balance of a weeping lovegrass treated with } 3 \text { sludge } \\
\text { application rates, and an unamended control }\end{array}$} \\
\hline \multirow[t]{2}{*}{ Treatment } & \multicolumn{5}{|c|}{ Four years cumulative total $\mathrm{P}$ mass balance } \\
\hline & $\begin{array}{l}\text { CUM-PS } \\
\left(\mathbf{k g} \cdot \mathrm{ha}^{-1}\right)\end{array}$ & $\begin{array}{l}\text { CUM-PU } \\
\text { (kg.ha-1) }\end{array}$ & $\begin{array}{l}\text { CUM-PS } \\
\text { less } \\
\text { CUM-PU } \\
\text { (kg·ha-1) }\end{array}$ & $\begin{array}{l}\text { Change } \\
\text { in soil P } \\
\text { storage } \\
\left(\mathrm{kg} \cdot \mathrm{ha}^{-1}\right) \\
\end{array}$ & $\begin{array}{c}\text { Mass } \\
\text { balance } \\
\text { difference } \\
\left(\mathrm{kg} \cdot \mathrm{ha}^{-1}\right)\end{array}$ \\
\hline Control & 0 & 59 & -59 & -50 & -9 \\
\hline $4 \mathrm{Mg} \cdot \mathrm{ha}^{-1} \cdot \mathrm{yr}^{-1}$ & 352 & 73 & 279 & 302 & -23 \\
\hline $8 \mathrm{Mg} \cdot \mathrm{ha}^{-1} \cdot \mathrm{yr}^{-1}$ & 705 & 93 & 612 & 660 & -48 \\
\hline $16 \mathrm{Mg} \cdot \mathrm{ha}^{-1} \cdot \mathrm{yr}^{-1}$ & 1409 & 102 & 1307 & 1316 & -9 \\
\hline
\end{tabular}

and organic matter particles can fix ammonium through the process of cation exchange. Moreover, ammonium can easily be immobilised by microbial biomass, and is also readily nitrified (Cameron and Haynes, 1986).

\section{Total P mass balance}

Sludge applications rates of $4 \mathrm{Mg} \cdot \mathrm{ha}^{-1}$ and higher resulted in a net positive total P mass balance (CUM-PS less CUM-PU) following 4 years of sludge applications and hay harvest events (Table 7, Column 4). Based on the mass balance calculation of total P imported with sludge less exported with weeping

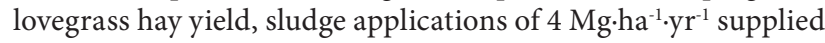
a cumulative excess of $279 \mathrm{~kg} \mathrm{P} \mathrm{ha}^{-1}$ during the 4-year study.

There was a mass balance difference (Table 7 , Column 6) between the P supply less uptake mass balance (Table 7 , Column 4) and the final less initial soil profile total P mass balance (Table 7, Column 5). The possible sources of difference are $\mathrm{P}$ content variation within the sludge matrix, soil heterogeneity and sampling errors.

The main reason for the accumulation of $\mathrm{P}$ in the soil profile was the low sludge $\mathrm{N}$ :P ratio compared with that of crops. Therefore, $\mathrm{P}$ accumulation is inevitable if sludge is applied according to crop N demand (Shober and Sims, 2003).

Changes in soil P storage from depths of $0.8 \mathrm{~m}$ (Table 7, Column 5) also supported the trends for the total P supply less uptake mass balance (Table 7, Column 4). Most of the excess $\mathrm{P}$ added with the sludge was located in the $0-0.1 \mathrm{~m}$ soil layer with a slight increase in the deeper $0.1-0.3 \mathrm{~m}$ soil layer (Fig. 4). The slight total $\mathrm{P}$ increment in this soil layer was most probably due to the physical migration of colloidal sludge particles between cracks formed during dry periods of the year, or from preferential flow of particulate $\mathrm{P}$ (Jensen et al., 2000; Brock et al., 2007). The grave concern with $P$ surface accumulation is the potential threat to surface water bodies through transport by runoff,
Total P (\%)

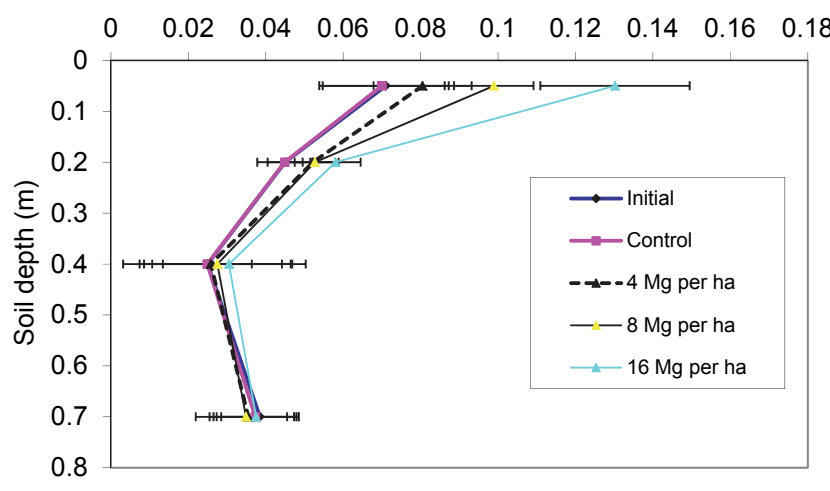

Figure 4

Initial soil profile total $P$ and after 4 consecutive years of municipal sludge application at 3 rates $\left(0,4\right.$, and $8 \mathrm{Mg} \mathrm{ha}^{-1}$ per year) and a zero control in a clay loam soil planted to weeping lovegrass

enhancing the rate of eutrophication in freshwater bodies (Carpenter et al., 1998).

\section{Soil profile residual Bray-1 extractable $P$}

Bray-1P decreased as the sludge application rate increased to

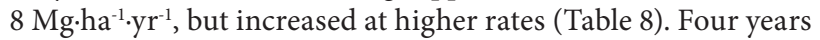
of sludge application according to the initial $8 \mathrm{Mg} \cdot \mathrm{ha}^{-1}$ limit reduced residual Bray- $1 \mathrm{P}$ by $42 \%$. This is in contrast to the net positive total $\mathrm{P}$ mass balance reported for the same treatment in Table 7 Columns 4 and 5. On the other hand, sludge applied at $16 \mathrm{Mg} \cdot \mathrm{ha}^{-1}$ increased residual Bray-1P in the top $0.5 \mathrm{~m}$ by $33 \%$

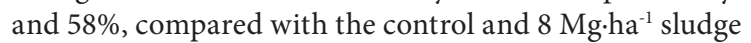
treatments, respectively.

Generally the mean background Bray-1P concentration of the soil in the $0-0.3 \mathrm{~m}$ soil stratum $\left(65 \mathrm{mg} \cdot \mathrm{kg}^{-1}\right)$ was higher than the optimum concentration required for most crops (25-30 mg. $\left.\mathrm{kg}^{-1}\right)$. It was also higher than the concentration for an optimum soil quality $\left(50 \mathrm{mg} \cdot \mathrm{kg}^{-1}\right)$, above which the risk for surface water body pollution increases, as reported by Sims and Pierzynski (2000).

The decline in Bray-1P reported for the 4 and $8 \mathrm{Mg} \cdot \mathrm{ha}^{-1}$ sludge treatments was mainly due to the $\mathrm{FeCl}_{3}$ added to the sludge at the waste treatment plants, which reduced the solubility of P (O'Connor et al., 2004; Huang et al., 2007). The build-up of Bray-1P reported from doubling of the sludge upper limit $\left(16 \mathrm{Mg} \cdot \mathrm{ha}^{-1}\right)$ is most probably because the P supply from the sludge exceeded the buffer capacity of the soil and sludge (Elliott and O'Connor, 2007), or because of a decline in the sludge's P-sorbing capacity over time (Lu and O'Connor, 2001). It is also possible that the Fe-P minerals may have released P by dissolution, as reported by Huang et al. (2007).

\begin{tabular}{|c|c|c|c|}
\hline \multicolumn{4}{|c|}{$\begin{array}{l}\text { TABLE } 8 \\
\begin{array}{l}\text { Residual Bray-1P in the top } 0.5 \mathrm{~m} \text { soil stratum after the second hay cut of dryland } \\
\text { pasture (weeping lovegrass) during the } 2004 / 05 \text { to } 2007 / 08 \text { growing seasons }\end{array}\end{array}$} \\
\hline Treatment & $\begin{array}{c}\text { Initial } \\
\left(\mathbf{k g} \cdot \mathrm{ha}^{-1}\right)\end{array}$ & $\begin{array}{c}\text { After } 2^{\text {nd }} \text { hay cut in } \\
2005 / 06 \\
\left(\mathrm{~kg} \cdot \mathrm{ha}^{-1}\right)\end{array}$ & $\begin{array}{c}\text { After } 2^{\text {nd }} \text { hay cut in } \\
2007 / 08 \\
\left(\mathrm{~kg} \cdot \mathrm{ha}^{-1}\right)\end{array}$ \\
\hline Control & 274 & 282 & 254 \\
\hline $4 \mathrm{Mg} \cdot \mathrm{ha}^{-1} \cdot \mathrm{yr}^{-1}$ & 274 & 253 & 230 \\
\hline $8 \mathrm{Mg} \cdot \mathrm{ha}^{-1} \cdot \mathrm{yr}^{-1}$ & 274 & 150 & 159 \\
\hline $16 \mathrm{Mg} \cdot \mathrm{ha}^{-1} \cdot \mathrm{yr}^{-1}$ & 274 & 367 & 378 \\
\hline
\end{tabular}


Therefore, it is apparent from this study that although sludge treated with $\mathrm{FeCl}_{3}$ reduced P plant availability, it is likely that $\mathrm{P}$ availability could also increase at higher rates over time.

Despite the high background concentration and additional $\mathrm{P}$ added with the sludge, there were no visible phosphorus toxicity symptoms during the study period. This is most probably due to the high $\mathrm{Zn}$ added with the sludge, because previous studies conducted by Loneragan et al. (1979), Safaya (1976), Parker (1997), and Silber et al. (2002) have shown that plant $\mathrm{P}$ toxicity is enhanced under $\mathrm{Zn}$-deficient conditions.

\section{CONCLUSIONS}

Weeping lovegrass hay yield increased with increase in sludge rate. Highest yield was harvested from years which experienced high rainfall. Sludge applied according to the WRC initial limit of $8 \mathrm{Mg} \cdot \mathrm{ha}^{-1} \cdot \mathrm{yr}^{-1}$ was not sufficient to satisfy weeping lovegrass $\mathrm{N}$ demand. Doubling that limit did not cause the accumulation of nitrate and ammonium in the soil profile. However, it increased both total and Bray-1P with time. Therefore, both of the initial hypotheses are accepted. It is recommended that long-term model simulations should be conducted under varying conditions in order to get a site-specific real-time ideal sludge application rate.

\section{ACKNOWLEDGMENTS}

We gratefully acknowledge the financial support of the Water Research Commission of South Africa (WRC), East Rand Water Care Works (ERWAT), and the Technology and Human Resources for Industry Programme (THRIP). We would like to thank ERWAT for providing the research site and numerous in-kind contributions. We are indebted to Mr JW Wilken, Dr Z Godongwana, and Mr Tseko from ERWAT, for their specific role in solving problems related to water, electricity, and sludge supplies. We also thank $\mathrm{Mr}$ du Plessis from the WRC and Dr H Snyman from Golder Associates for their encouragement and motivation since the inception of the study.

\section{REFERENCES}

ADAMSEN F and SABEY B (1987) Ammonia volatilization from liquid digested sewage sludge as affected by placement in soil. Soil Sci. Soc. Am. J. 51 1080-1082.

AGEHARA S and WARNCKE D (2005) Soil moisture and temperature effects on nitrogen release from organic nitrogen sources. Soil Sci. Soc. Am. J. 69 1844-1855.

BARY AI, COGGER CG, FRANSEN SC and SULLIVAN DM (2001) Seven years of biosolids versus inorganic nitrogen applications to tall fescue. J. Environ. Qual. 30 2188-2194.

BOYLE M and PAUL E (1989) Carbon and nitrogen mineralization kinetics in soil previously amended with sewage sludge. Soil Sci. Soc. Am. J. 53 99-103.

BROCK EH, KETTERINGS QM and KLEINMAN PJA (2007) Phosphorus leaching through intact soil cores as influenced by type and duration of manure application. Nutr. Cycling Agroecosyst. 77 269-281.

CAMERON KC and HAYNES RJ (1986) Retention and movement of nitrogen in soils. In: Haynes RJ (ed.) Mineral Nitrogen in the PlantSoil System. Academic Press, New York.

CARPENTER SR, CARACO NF, CORRELL DL, HOWARTH RW, SHARPLEY AN and SMITH VH (1998) Nonpoint pollution of surface waters with phosphorus and nitrogen. Ecol. Appl. 8 559-568.

DICKISON EB, HYAM GFS, BREYTENBACH WAS, METCALF HD, BASSON WD, WILLIAMS FR, PLINT AP, SMITH HRH, SMITH PJ, VAN VUUREN PJ and co-authors (2004) Kynoch pasture handbook. Kejafa Knowledge Works, Maanhaarrand, South Africa. DOTSON K (1973) Some constraints on spreading sewage sludge on cropland. Compost Sci. 14 12-15.

ELLIOTT H and O'CONNOR G (2007) Phosphorus management for sustainable biosolids recycling in the United States. Soil Biol. Biochem. 39 1318-1327.

FERREIRO-DOMÍNGUEZ N, RIGUEIRO-RODRÍGUEZ A and MOSQUERA-LOSADA M (2011) Response to sewage sludge fertilisation in a Quercus rubra L. silvopastoral system: Soil, plant biodiversity and tree and pasture production. Agric. Ecosyst. Environ. 141 49-57.

HENRY C, SULLIVAN D, RYNK R, DORSEY K and COGGER C (1999) Managing Nitrogen from Biosolids. Washington State Department of Ecology, Seattle, WA.

HUANG XL, CHEN Y and SHENKER M (2007) Soil phosphorus phase in aluminium and iron treated biosolids. J. Environ. Qual. 36 549-556.

JENSEN MB, OLSEN TB, HANSEN HCB and MAGID J (2000) Dissolved and particulate phosphorus in leachate from structured soil amended with fresh cattle faeces. Nutr. Cycling Agroecosyst. 56 253-261.

LAKHDAR A, SCELZA R, SCOTTI R, RAO MA, JEDIDI N, GIANFREDA L and ABDELY C (2010) The effect of compost and sewage sludge on soil biologic activities in salt affected soil. R.C. Suelo Nutr. Veg. $1040-47$.

LONERAGAN J, GROVE T, ROBSON A and SNOWBALL K (1979) Phosphorus toxicity as a factor in zinc-phosphorus interactions in plants. Soil Sci. Soc. Am. J. 43 966-972.

LU P and O'CONNOR GA (2001) Biosolids effects on phosphorus retention and release in some sandy Florida soils. J. Environ. Qual. 30 1059-1063.

MAGUIRE R, COALE F and SIMS J (2000) Phosphorus solubility in biosolids-amended farm soils in the Mid-Atlantic region of the USA. J. Environ. Qual. 29 1225-1233.

MARTINES A, NOGUEIRA M, SANTOS C, NAKATANI A, ANDRADE C, COSCIONE A, CANTARELLA H, SOUSA J and CARDOSO E (2010) Ammonia volatilization in soil treated with tannery sludge. Bioresour. Technol. 101 4690-4696.

MILES N and MANSON A (2000) Nutrition of planted pastures. In: Tainton NM (ed.) Pasture Management in South Africa. University of Natal Press, Pietermaritzburg.

MILNE R and GRAVELAND D (1972) Sewage sludge as a fertilizer. Can. J. Soil Sci. 52 270-273.

NEAL C, JARVIE HP, WADE AJ and WHITEHEAD PG (2002) Water quality functioning of lowland permeable catchments: inferences from an intensive study of the River Kennet and upper River Thames. Sci. Total Environ. 282 471-490.

NEUNHÄUSERER C, BERRECK M and INSAM H (2001) Remediation of soils contaminated with molybdenum using soil amendments and phytoremediation. Water Air Soil Pollut. 128 85-96.

NON-AFFILIATED SOIL ANALYSIS WORK COMMITTEE (1990) Handbook of Standard Soil Testing Methods for Advisory Purposes. Soil Science Society of South Africa, Pretoria.

O'CONNOR G, SARKAR D, BRINTON S, ELLIOTT H and MARTIN F (2004) Phytoavailability of biosolids phosphorus. J. Environ. Qual. 33 703-712.

OJEDA G, ALCAÑIZ J and LE BISSONNAIS Y (2008) Differences in aggregate stability due to various sewage sludge treatments on a Mediterranean calcareous soil. Agric. Ecosyst. Environ.125 48-56.

PARKER D (1997) Responses of six crop species to solution zinc ${ }^{2+}$ activities buffered with HEDTA. Soil Sci. Soc. Am. J. 61 167-176.

PIERZYNSKI GM (1994) Plant Nutrient Aspects of Sewage Sludge, Sewage Sludge: Land Utilization and the Environment. Soil Science Society of America, Madison, WI.

SAFAYA N (1976) Phosphorus-zinc interaction in relation to absorption rates of phosphorus, zinc, copper, manganese, and iron in corn. Soil Sci. Soc. Am. J. 40 719-722.

SAS INSTITUTE (2002) PROC User's Manual Version 9.1. SAS Institute Cary, NC.

SHOBER AL and SIMS JT (2003) Phosphorus restrictions for land application of biosolids. J. Environ. Qual. 32 1955-1964. 
SILBER A, BEN-JAACOV J, ACKERMAN A, BAR-TAL A, LEVKOVITCH I, MATSEVITZ-YOSEF T, SWARTZBERG D, RIOV J and GRANOT D (2002) Interrelationship between phosphorus toxicity and sugar metabolism in Verticordia plumosa L. Plant Soil 245 249-260.

SIMS J and PIERZYNSKI G (2000) Assessing the impacts of agricultural, municipal, and industrial by-products on soil quality. In: Power J, Dick W, Kashmanian R, Wright R, Dawson M and Bezdicek D (eds.) Land Application of Agricultural, Industrial, and Municipal By-Products. Soil Science Society of America, Madison, WI

SMITH MTE and TIBBETT M (2004) Nitrogen dynamics under Lolium perenne after a single application of three different sewage sludge types from the same treatment stream. Bioresour. Technol. $91233-241$.
SNYMAN HG and HERSELMAN J (2006) Guidelines for the Utilisation and Disposal of Wastewater Sludge. WRC Report No. TT 262/06. Water Research Commission, Pretoria.

SOIL CLASSIFICATION WORKING GROUP (1991) Soil Classification: A Taxonomic System for South Africa. Department of Agricultural Development, Pretoria.

TESFAMARIAM EH, ANNANDALE JG, STEYN JM and STIRZAKER RJ (2009) Exporting large volumes of municipal sewage sludge through turfgrass sod production. J. Environ. Qual. 38 $1320-1328$.

XIE C, ZHAO J, TANG J, XU J, LIN X and XU X (2011) The phosphorus fractions and alkaline phosphatase activities in sludge. Bioresour. Technol. 102 2455-2461. 